\title{
FROM THE HISTORY OF ANCIENT MEMORIES IN UZBEKISTAN (AS AN EXAMPLE 60-70 OF XX CENTURY)
}

\author{
Dilnoza Ulugbekovna Yuldasheva \\ Teacher of the chair of \\ "History of Uzbekistan" of \\ Andizhan State University \\ Named after Babur, \\ Andizhan region, \\ Republic of Uzbekistan
}

Article D0I: https://doi.org/10.36713/epra2886

\begin{abstract}
In this article has been expressed condition of ancient material culture memorials in Uzbekistan during the 1960-1970s of Soviet government and also their guarding processes by the helping archive materials and historical literatures as well. In this research investigated that in the 1960s ideas was introduced into the socio-political life. Besides, author showed that the memorial museum has exhibited photos, photographs, historical sites, industrial enterprises, which reflect the biography and activities of the statesman, over 90,000 visitors visited the museum during this time, with over 300 thematic tours, since the 1960s, museums in Uzbekistan have laid the groundwork for new methods of mass cultural work. In particular, on the basis of the Museum of the History of Peoples of Uzbekistan a "traveling museum" was established, its employees visited the state, collective farms and also showed the audience the unique treasures and material resources of the museum, valuable exhibits and revolutionary monuments.
\end{abstract}

KEY WORDS: Material culture memorials, Historical museum, historical literatures, culture, expedition, ethnographical branch, ideology, exposition, Uzbekistan.

\section{INTRODUCTION}

It is well-known that in the 1960s, the idea of artificial "advanced socialism" was introduced into the socio-political life of the Soviet society. This, in turn, did not bypass the cultural sphere, and at the same time this idea was applied to the spiritual and cultural life of Uzbekistan. At that time, the principles of freedom inherent in culture and an important factor in its development were also completely eliminated. However, the cultural sphere continued to evolve to a certain extent, despite all the ideological pressures and molding. At that time, the preservation and protection of the material and cultural monuments was provided by museums, which are cultural institutions. The National Museum of History, which operates in the country, has organized special expeditions to study historical periods from 1959 onwards. In particular, he focused on collecting materials in industry, agriculture, science and culture [1], [37]. The main basis for carrying out scientific researches and research in the museum are the monuments and treasures kept in its funds. For this reason, the museum has focused on working on funds. In 1959-1961 the museum made a complete registration and its collections were divided into archeology, numismatics, ethnology, souvenirs, scientific archives. For example, the museum had more than 25,000 archeological exhibits, 30,000 coins and medals, about 12,000 ethnographic items and 1,200 artifacts [2], [71]. Also, in 1960-1961, exhibits of the museum were enriched with musical instruments of Tashkent, Pskent embroidery, Sovietera clothing. At the same time, a special expedition to Surkhandarya region was organized to examine the lifestyles of community members. During this expedition numerous samples of their home appliances and weapons were found.

It is important to note that in 1960-1961 over 5,000 newly discovered exhibits were presented to the museum. In 1962, the museum departments were given more than 4,000 additional exhibits. The number of rare exhibits collected during expeditions organized by the academician M.Andreev in the ethnology department of the museum increased [3], [46]. Among the exhibits are ceramics made in Rishtan, Kokand, Isfara and Chust, which made a 
great impression on visitors. On June 27, 1962, the Ministry of Culture of the UzSSR allocated 34,000,000 rubles to the Main Department for the Preservation of Material Cultural Monuments and Museums for the reconstruction and consolidation of historical and cultural monuments [4], [24]. At the same time, these funds were used to equip the museums with technical equipment and to organize transport services in cultural institutions.

\section{METHODS}

In the 1960s, as a result of the expansion of atheistic propaganda by the Soviet government, religious sites were stamped on the Birdamlik main sanctuary in Andizhan, and at the initiative of the city executive committee, the place was demolished with bulldozers and excavators [5], [103]. Thus, this longserving and near-town shrine for the population of Andizhan region was destroyed during the Soviet era. During these years of Soviet rule, memorial museums reflecting the activities of historical figures and statesmen were established. In particular, by the decision of the Council of Ministers of the UzSSR on October 17, 1964, a memorial museum dedicated to Yuldash Ahunboboev was opened in Margilan, Ferghana region [6], [35]. The memorial museum has exhibited photos, photographs, historical sites, industrial enterprises, which reflect the biography and activities of the statesman. For example, over 90,000 visitors visited the museum during this time, with over 300 thematic tours. Since the 1960s, museums in Uzbekistan have laid the groundwork for new methods of mass cultural work. In particular, on the basis of the Museum of the History of Peoples of Uzbekistan a "traveling museum" was established, its employees visited the state, collective farms, and showed the audience the unique treasures and material resources of the museum, valuable exhibits and revolutionary monuments [7], [28]. In 19621964, the Museum of History of the People of Uzbekistan produced 19 traveling and permanent museum exhibitions. Also, in connection with the $40^{\text {th }}$ anniversary of the establishment of the Uzbek Soviet Socialist Republic, mass-educational work in museums intensified, and the Museum of History of Peoples of Uzbekistan developed a series of lectures based on material items and treasures of the type of monuments of the revolution that are stored in its treasury. In 1964, museum staff gave more than 500 lectures. Taking into account the needs and requirements of amateurs, the museum organized tours of the museum "Tashkent architectural monuments" and "Places related to revolutionary events".

\section{RESULTS AND DISCUSSIONS}

It should be noted that the architecture and art of Uzbekistan during the former Soviet Union came under the influence of alien ideas and were formed on the basis of stereotypes that contradict
Uzbek national values. It was during this time that the centuries-old values of great cultural heritage, spiritual values and national perfection to undermine the national pride were banned. In particular, the heritage and names of the great ancestors, even the sacred places and shrines on which their hills lie, have been destroyed. For example, 'Imam Bukhari's mausoleum in Samarkand region during Soviet era shows how badly it looked at our national cultural heritage during the reign of violent ideology when the Kaffol Shoshi mausoleum in Tashkent was converted into a bazaar or Odina mosque in Karshi” [8], [5].

From the second half of the 1960s, special attention was paid to the study of ancient and historical monuments in Samarkand. In particular, the Central Committee of the Communist Party of Uzbekistan adopted a special resolution on July 13, 1966, "On measures for further historical and archeological research of the ancient city of Afrosiab" [9], [33]. According to this resolution, the town was declared a place of archeological excavations, and special measures were taken to protect and preserve it, and to explore the town. At the same time, the decision gave an impetus to the comprehensive study of archeological monuments in the city and to the study of the history and archeology of Afrosiab, one of the largest centers of civilization in Central Asia.

On March 27, 1967 by the decision of the Council of Ministers of the UzSSR "Society for Preservation of Historical and Material Cultural Monuments of the Uzbek SSR" was established [10], [87]. In a sense, the society aims to organize and preserve the existing monuments in the country. As of January 1, 1969, about 8,000 primary community organizations were established in Uzbekistan, its staff and members visited the ancient cities of Bukhara and Samarkand, Khorezm, Kashkadarya and Andijan regions and assisted local cultural departments.

According to the decision of the Council of Ministers of the Communist Party of Uzbekistan on November 30, 1967 “About preservation, improvement, design and construction of historical and architectural monuments in Khiva”, Ichan Kala is considered as Khiva State Architectural Reserve. At the same time, systematic protection, preservation and restoration of historical and artistic architectural monuments in Ichanqala was carried out step by step. In 1969, the Khorezm Regional History Museum and the Ichan Kala Nature Reserve Museum were established. Its functions included the research, scientific and educational establishment and the preservation and protection of state historical, art, literary and artistic monuments. The establishment of the reserve has given impetus to the study of architectural monuments, as well as the study of residential buildings in Ichan Kala.

On May 14, 1968, the Council of Ministers of the Communist Party of Uzbekistan and the 
Council of Ministers of the Uzbek SSR adopted a resolution "On measures to further improve cultural and public services and the preservation of historical and architectural monuments in the city"[11], [43]. According to this resolution, the main task is to study, preserve and restore the unique historical monuments, and the State Construction Committee of the UzSSR is tasked with modernizing the city and considering the ancient architectural monuments.

The unique architectural buildings in Bukhara - the epigraphic ornaments of the madrasahs of Abdulazizkhon and Nodir devonbegi, in particular, the madrasahs are decorated with animal figures legendary birds, deer, dragons. These cultural buildings are mostly rectangular and square shaped, and the new architecture of the Timurid period has a distinctive "kundal" direction in urban architecture [12], [84]. It should be noted that according to the above-mentioned decision, the works on repairing timbers and towers related to monumental architectural monuments in Bukhara were also specified. Most of them were built and owned in the sixteenth century, and they were built in the city center, mainly at the crossroads of caravan routes. Four of the largest trading facilities in Bukhara, namely Taki Zargaron, Toki Telpakfurushon, Toki Sarrafon and Abdullakhan, have been preserved [13], [1], [2]. It should be noted that the term "arc" is used in the sense of "arc" and "dome" and also for large market buildings with a dome roof. They specialize in commerce and architecturally harmonize highways.

On May 15, 1968, at the third session of the Supreme Soviet of the UzSSR, the Law "On the Protection of Cultural Monuments" was adopted, which established measures for the establishment and systematic protection of cultural and historical monuments. At the same time, it is expedient to analyze the implementation of this law in all regions of the country in the historic Samarkand region. Specifically, this year, 54 national-level monuments (including 23 architectural monuments, 30 archeological and 1 art monuments) and 694 local monuments were under state protection in Samarkand [14], [113].

In order to identify and identify cultural monuments in the districts of Samarkand region departments of the Society for the Preservation of Historical and Cultural Monuments of Uzbekistan have been established. In 1968, the working committees of the Samarkand regional and city councils, the Ministry of Culture, and its Main Department for the Preservation of Monuments and Fine Arts conducted activities to investigate and repair world-renowned monuments, such as the Sherdor, Ulugbek, Tillakori madrassas, Shakhizinda, Gur Emir's tombs. A comprehensive expedition of the Institute of History and Archeology of the Academy of Sciences of the Republic of Uzbekistan, Institute of Art Studies of the Ministry of Culture of the Republic of Uzbekistan, Tashkent State University (NUU) and SamSU conducted a survey of Afrosiab town. Also, the Arabata Mausoleum in Tim, the Resurrection Wall, and Kumushkontepa were studied in detail. Specialists from a number of cultural institutions in Moscow, Tashkent and Samarkand were involved in these events.

During the first 10 months of $1968,428,000$ rubles were allocated for the reconstruction and protection of cultural monuments in Samarkand, or 80 percent of the total funds allocated for these purposes. In 1968 and 1969, 65 sections of the Society for the Preservation of Historical and Cultural Monuments of Uzbekistan have identified and registered 65 more architectural and historical monuments. The establishment of a tourist bureau in the region has contributed to an increase in the number of visitors to the cultural sites. For example, as a result of the work done by the bureau, only in 1968 and in the last ten months of 1969, cultural monuments were visited by about 150,000 people, including 22,000 foreigners [15], [114].

On January 15, 1970, the Council of Ministers of the Central Committee of the Communist Party of Uzbekistan and the Cabinet of Ministers of the Republic of Uzbekistan adopted a resolution "On the state of sculptural art in the Republic and measures for its further development" [16], [106]. After the adoption of this decision, chairmen of regional societies for the protection of monuments of the republic, city and district Soviet societies were identified and revised their status on the ground. As a result, it was learned that all the historical and revolutionary art monuments were taken into account, most of them were attached to the leading organizations, and the practical implementation of each monument (improvement and small repairs) was practically done. However, the accomplishment and reconstruction of the monuments were not fully implemented in all regions of the country. For example, in Kuva, Akhunboboev, Baghdad and Ferghana districts, where individual monuments are located, landscaping has not been done and no outreach activities have been carried out. At the same time, little attention has been paid to the acceleration and repair of monuments in Kokand and Rishtan districts [17], [380].

In the early $1970 \mathrm{~s}$ it was discovered that there are more than 400 unique architectural sites in the country. More than 200 historical and revolutionary monuments were erected during the Soviet era. Unique architectural monuments of the country are considered by such international organizations as UNESCO, such as Gur Amir Mausoleum in Samarkand, Bibikhonim Mosque, magnificent Registan Ensemble, Shahizinda Ensemble, and Kalon Ensemble in Bukhara [18], [14].

In 1970, as a result of increasing the effectiveness of Ya.Gulomov's scientific work, a new 
Institute of Archeology of the Academy of Sciences of Uzbekistan was opened in Samarkand. This event has contributed to the development of archeological works and development of scientific researches not only in the city of Samarkand, but also in the country. As a result, in many regions archaeological monuments have been opened in a broad planographic manner, a full and complete study of the openings, and on this basis a complete study of ancient buildings, streets, neighborhoods, craft centers and relics. As a result, there was a problem of preserving the buildings in the open space and transforming them into open-air archeological resorts - museums. Expansion of scientific research topics in this regard led to the conversion of the laboratory in 1971 to the special section of the Institute of Archeology of the Academy of Sciences of Uzbekistan, "Chemical-technological research and repair of historical monuments". One of the main tasks of this department is to create methods for the storage of structures made of raw brick, cauldrons and shapes made of clay.

In accordance with the decision of the Central Committee of the Chamber of Commerce of the Republic of Uzbekistan on August 23, 1972, the issues of sculpture development and further development of the art in the republic and the preservation of monuments in the regions, protection of monuments [19], [107]. In addition, the Permanent Commission for the Protection of Natural and Cultural Monuments, in cooperation with the Republican Society for the Preservation of Monuments, has begun the reconstruction of sculpture. These events gave an opportunity to take into account monumental art installations in cities and districts, and these works were sponsored by local organizations. The Society for the Protection of Monuments has issued a series of illustrative posters and more than 20,000 leaflets. The execution of the above resolution was not implemented satisfactorily in all regions of the country. In particular, the sculpture and sculpture of Altyaryk district of Ferghana region and cities of Ferghana were not registered. Not much attention has been paid to the construction of new monuments on the ground, including no one in the past three years in Ahunbabaev district (there are 32 monuments, 15 of which were built in the 1940s and 1950s) [20], [108].

In 1973, the Council of Ministers of the UzSSR approved a list of 10 ancient cities in order to improve the protection, restoration and repair of cultural heritage in the country and emphasized the need for their protection [21], [3], [4]. The list also focuses on the protection of rare architectural ensembles and monumental monuments in Kokand. In the Ferghana Valley, only a few 19th-century architectural monuments of Andizhan, Namangan and Kokand were under state protection, and shortly thereafter, more than 100 monuments of the 16th19th-century Ferghana architectural art were located in various districts of the valley. At the same time, on December 21, 1973, 81 cultural monuments in Ferghana region were taken under state protection. 7 of them are architectural monuments, 8 - historical and artistic monuments, 66 - archaeological monuments. The oldest architectural monuments here are the Kamolkozi Madrasah (1847), the Madyan Khazrat Madrassah (1861), the Norbutabi Madrassah (1799), the Mosque of the House (XVIII century), Dakhmai Shahona (XIX century) and Modarihon (XIX century). After the state protection of these unique architectural buildings, these settlements and the Khudayarkhan Horde (1873) were reconstructed and repaired.

In 1970-1975 the number of cultural institutions in the country increased. In particular, there were 6,300 libraries, 31 museums and 3,700 clubs. By 1985, labor collectives served 1,667 red corners, 25,981 communist labor schools, 939 clubs for 294069 , including palaces and houses of culture. The museums, which belong to this category, contain various monuments, material and artifacts, works of art, and sculptures related to the past of the Uzbek people.

It is noteworthy that in February 1975, the Central Committee of the Communist Party of Uzbekistan adopted a special resolution "On measures to further improve the protection, restoration, promotion and promotion of architectural, historical and artistic and architectural monuments in Uzbekistan. According to the resolution, the task is to repair and repair the material and cultural monuments in the republic, including archeological monuments and preserve historical monuments. After the decision, archeological monuments throughout the country were repaired and repaired, large-scale reconstruction works were carried out to restore the ruined cultural sites on the ground.

The reconstruction of historical and cultural monuments, in turn, is inextricably linked with the experience and skills of architects and craftsmen, the educational process. It is important to note that in the second half of the Soviet 1970s, the country lacked specialists in this field. The main reason for this was the lack of attention of the central government to the renovation of the architectural monuments and the neglect of the industry. However, in 1976 the younger generation was taught at the Samarkand Institute of Architecture and Construction and other secondary education institutions for the repair and restoration of historical and cultural monuments and monuments. Unfortunately, the archeological sites in many areas have been destroyed and require a complete overhaul. The funds allocated by the Soviet cultural authorities for the restoration of monuments were insufficient.

A number of measures were taken to preserve, preserve and study archeological monuments in the Republic. The law of the Supreme 
Soviet of the UzSSR "On preservation and use of monuments of history and culture" of 1977 and the decision of the Council of Ministers of the Communist Party of Uzbekistan of September 23, 1979 "On measures for further development of archeological research in the Republic" much attention was paid to the scientific study of archaeological finds from the past [22], [670]. However, the resolution also states that archeological sites are being destroyed on the ground. In particular, archaeological sites in the Romitan district and October $50^{\text {th }}$ anniversary of Romitan district of Bukhara region are in ruins. One of the oldest cities in the Kashkadarya region - Kallai Zakhakimaron, Shuluktepa and Erkurgan were destroyed. The ancient city of Turtkul in the Tashkent region has been completely destroyed due to the neglect of the history and culture departments. During the last 6 years Uzkolkhozstroy organizations have destroyed 6 archaeological sites in Samarkand region and 10 in Namangan region.

The decision of the Central Committee of the Communist Party of Uzbekistan of February 22, 1977 "On the further improvement of the preservation of monuments in the republic and their use in ideology" entrusted the party, Soviet and cultural departments to use them as a visual weapon for propaganda of the monuments [23], [98]. According to the resolution, tasks on protection of historical and cultural monuments in the republic, their repair and repair at the local level were defined. At the same time, the reconstruction of the memorials was carried out by other organizations as well. In particular, the work of preserving and preserving the centuries-old cultural heritage of the Uzbek people was carried out by the Scientific Center established in Tashkent, the Research and Design Institute of the Monuments of Uzbekistan. This research institute has studied the historical monuments of the republic during the Soviet era. Thanks to the hard work of such masters as Aminjon Salomov and Ochil Bobomurodov in Bukhara, the Madrassahs of Masjidi Kalon, Minorai Kalon, Ulugbek and Kukaldosh were reconstructed.

Capital funds for the reconstruction of mosques and madrassas in the Ferghana region were disbursed and used. In particular, in the plan of repair works of the Republican Society for the Preservation of Historical and Cultural Heritage of Uzbekistan on February 22, 1979, 72,000 rubles were allocated for the reconstruction of the architectural monuments in the Fergana region [24], [15]. It is important to note that as a result of the management's allocation of capital funds to these architectural structures, their condition has improved and changed.

According to the Central Committee of the Communist Party of Uzbekistan, in 1979 the Ministry of Culture of the Republic of Uzbekistan established the Main Department for the Scientific Production of Souvenirs. The department has increased funding for the conservation and restoration of monuments. During the tenth five years (1976-1980) the volume of these events increased by 2.5 times. In particular, the Registan Ensemble Square in Samarkand, the Labihovuz Ensemble in Bukhara and the Ichanqala Historical Museum in Khiva have been renovated. Famous masters from Samarkand B. Juraev, A. Umarov, K. Jalilov, A. Kuliev, A. Hakkulov, R.Masharipov, T.Yokubov, I.Rajabov from Kokand, S.Muydinov from Kokand, Namangan T.Fozilov, K.Yunusov and T.Ismoilov from Andijan contributed greatly. At the same time, the Law of the Supreme Soviet of the UzSSR "On the preservation and use of monuments of history and culture" emphasized that the promotion of cultural heritage is one of the main tasks of the Society for the Preservation of Historical Monuments. In its outreach, the society used public events and various means.

In 1980, a group of lecturers was established in the city and district centers of the country, bringing together about 2,000 public advocates. Tours and excursions of schoolchildren were held to familiarize with the monuments and historical monuments. The 32 tourist itineraries developed by the LKSM of Uzbekistan include more than 200 of the best national monuments in the country, and more than 10,000 members of the community visit these sites every year.

The Republican Society for the Preservation of Historical and Cultural Monuments has revived its efforts to publish information on the unique monuments of the country. In particular, in the tenth fifteenth year (1976-1980) books on architectural monuments of Khorezm, Shahzinda ensemble, Central Asian architectural monuments, Tashkent architectural center and other cultural monuments were published. These publications contain information about unique architectural structures in Uzbekistan - mosques, madrasas, historical monuments. At the same time, the above works analyzed the issues of reconstruction and repair of cultural buildings in need of repair.

In 1980 special car clubs were created by the Republican Society for the Preservation of Historical and Cultural Monuments. They served in the most remote areas of the country, delivered lectures, film screenings and photographic presentations on ancient architectural structures of Samarkand, Bukhara and Khiva at community farms and field halls and rural schools. In 1980 alone, members of the Society of History and Culture of Uzbekistan gave more than 10,000 lectures, organized over 500 broadcasts on radio and television, film festivals and weeks of memorials. The film "yesterday, today, tomorrow" dedicated to the architectural monuments of the Ferghana Valley cities was prepared and shown by members of the given society. In particular, the film "Restoration" tells about the history of Turkestan, which was shown in stone and bronze, about the Uzbek warriors of World War II, which contains 
memorials and monuments of honor that perpetuate their memory.

In the late 1970s archeological excavations were carried out in historic cities of the Republic. In particular, due to the development of the architectural monuments restoration project Ichan Kala in Khiva, the specialists were able to dig a number of ditches and find valuable ceramic items. Having studied these findings, M. Mambetullaev found fragments of ceramic vessels dating from the fourth and third centuries BC, testifying to the ancient Khorezm period. In 1973 - 1975, the same scientist studied the city walls of Ichan Kala. It should be noted that the coins kept in the Khiva Museum in 1969 (according to Treasurer of the Museum T.Sereda, these coins were found in the territory of Ichan Kala) are of ancient and medieval coins [25], [23]. Thus, as a result of archeological excavations in the republic, the opportunity to collect and accumulate material and cultural values was obtained.

\section{CONCLUSION}

In summary, some work has been done to preserve and preserve historical, cultural monuments in the country during the "advanced socialism" phase and in the 1970s. At the same time, special car clubs of the Republican Society for the Preservation of Historical and Cultural Monuments were organized and delivered lectures. In order to promote the monuments, the members of the community traveled to remote areas and remote areas of the country to present unique lectures, film screenings, and photo exhibitions on collective architects, field halls and rural schools in Samarkand, Bukhara, and Khiva. Numerous broadcasts have been made through radio and television, and festivals and weeks of film about monuments have been made. However, these events unfortunately were carried out in the form and style of Soviet ideology.

\section{REFERENCES}

1. National Archives of Uzbekistan (NAUz), R.Fund-2296, List-1, folding volume-312.

2. N.Sodikova, Yu. Buryakov. Treasury of Historical Monuments.-Tashkent: Fan, 1981.

3. NAUz, R.Fund-2296, List-1, folding volume-312.

4. NAUz, R.Fund-2296, List-2, folding volume-86.

5. R.Shamsutdinov, M.Saidkhonov, Sh.Kahhorov. Birpustin - shrine, shrine, camp // Vodiynoma.Andizhan, 2018. -2 (9).

6. N.Sodikova. Memorial Museum of Yuldash Ahunboboev.-Tashkent: Fan, 1979.

7. NAUz, R.Fund-2296, List-2, folding volume-86.

8. Uzbek Architecture and Monumental Sculpture during the Independence / Editorial Board: H. Sultonov et al. -Tashkent: Publishing House of Arts, SMI-ASIA, 2011.

9. NAUz, R.Fund-2296, List-7, folding volume-530.

10. NAUz, R.Fund-2296, List-1, folding volume-454.

11. NAUz, R.Fund-2296, List-7, folding volume-530, p.43.
12. D.Sultanova. Epigrafical Ornaments in Architecture of Uzbekistan // International Journal of Scientific \& Technology Research.India, Volume 4, Issue 07, July 2015.

13. G.A.Pugachenkova. Tim and the rocks. Architectural monuments of Bukhara-Tashkent: Uzbekistan, 1965.

14. Ferghana regional state archive (FRSA), Fund1160, List-1, folding volume-5.

15. FRSA, Fund-1160, List-1, folding volume-5, p.114.

16. NAUz, R.Fund-2296, List-4, folding volume-34.

17. FRSA, Fund-1160, List-1, folding volume-21.

18. T.Kari-Niyoziy. Preservation and study of monuments of material culture of the Uzbek SSR.-Tashkent: Fan, 1971.

19. NAUz, R.Fund-2296, List-6, folding volume-435.

20. FRSA, Fund-1160, List-1, folding volume-5.

21. I.Azimov. Architectural monuments of the Ferghana Valley.-Tashkent: Uzbekistan, 1986.

22. NAUz, R.Fund-2296, List-5, folding volume-570.

23. NAUz, R.Fund-94, List-2, folding volume-343.

24. FRSA, Fund-1160, List-1, folding volume-98.

25. I.Jabborov, E.Rtveladze, etc. Khiva Thousand Dome - Tashkent: Shark, 1997. 